\title{
Contribution of Turkish Articles About Emergency Medicine to The International Literature
}

\author{
Türkiye’de Acil Tıp Alanında Yayınlanmış Makalelerin Dünya Tıp Literatürüne Katkısının Analizi
}

\begin{abstract}
Kuşku Kıyak S', Akdeniz YS², Ozturk M$^{3}$, Kıyak OG ${ }^{4}$, Ipekçi A², Aydın Y ${ }^{5}$, Ikizceli I ${ }^{2}$
1-Sağlık Bakanlığı Fehime Faik Kocagöz Devlet Hastanesi, Söke, Aydın, Türkiye. 2-İstanbul Üniversitesi-Cerrahpaşa, Cerrahpaşa Tıp Fakültesi, Acil Tıp Anabilim Dalı, İstanbul, Türkiye. 3-Sağlık Bilimleri Üniversitesi, İstanbul Haseki Uygulama ve Araştırma Merkezi, Acil Tıp Anabilim Dalı, İstanbul, Türkiye. 4-Sağlık Bakanlığı, Çırpı Aile Sağlı̆̆ı Merkezi, Bayındır, İzmir, Türkiye. 5-Sağlık Bakanlığı Silivri Devlet Hastanesi, Acil Servis, Edirne, Türkiye.
\end{abstract}

\begin{abstract}
Objective: This study aimed to present characteristics of internationally published articles about emergency medicine originating from Turkey between 2002-2012 years.

Methods: For our evaluation, all articles about emergency medicine published in Science Citation Index and Science Citation Index Expanded between 2002-2012 years were included. The articles were categorized according to subjects, hospitals, departments, years. The International Scientific Indexing Web of Knowledge was searched for all articles.

Results: A total of 1812 articles were included. Of all articles, $64,3 \%(n=1165)$ were published in the last five years. Publications in the last five years were detected to increase at a rate of $4,6 \%$ per year. $78,1 \%$ $(n=1416)$ of the articles were published in non-Emergency Medicine journals. "Turkish Clinics" journal in the non-Emergency Medicine journals group, with 46 articles, and the "Turkish Journal of Trauma and Emergency Surgery" in the Emergency Medicine group, with 134 articles, were the preferred journals. The most popular subjects were trauma, at $14,7 \%(n=266)$, followed by emergency medicine and management, at $14 \%(n=253)$.

Conclusion: Significant publication growth was detected related to the development of Emergency Medicine in Turkey. The preference of non- Emergency Medicine journals, trauma as the most popular subject, and the effect of university hospitals were the interesting results of this study. The low number of multicenter trials and published articles in high impact factor journals have led us to consider the importance of publication quality, which requires additional effort.

ÖZET

Amaç: Türkiye'de Acil Tip alanında uluslararası literatürde yayınlanmış bilimsel çalışmaların genel karakteristik özelliklerini ortaya koymaktır.

Gereç ve Yöntem: Değerlendirme için ABD'de Science Citation Index ve Science Citation Index Expanded 'ta 2002-2012 yilları arasında Acil Tip alanında yayınlanan makaleler seçilmişstir. Seçilen makaleler konulara, hastanelere, bölümlere ve yillara göre sinfflandırllmıştır. Araștırma bilgisayar ortamında "International Scientific Indexing Web of Knowledge" kullanılarak yapılmıştır.

Bulgular: Çalışmaya dâhil edilen 1812 makalenin \%64,3'ünün (n=1165) son 5 yllda yayınlandığı, son beş yılda artış oranının yılda \%4,6 olduğu saptandl. Tüm makalelerin \%78,1'lik (n=1416) bir oranı acil tıp kategorisi dışındaki dergilerde yayınlanmıştır. Bu kategoride en popüler dergi 46 makale ile "Türkiye Klinikleri Dergisi" olurken, acil tip kategorisinde ilk sirayt 134 makale ile "Ulusal Travma ve Acil Cerrahi Dergisi” almıstır. En sık travma \%14,7 (n=266) ve acil tıp ve yönetimi \%14 $(n=253)$ konularında makale gönderilmiştir.

Sonuç: Türk acil tıbbındaki gelişmelere paralel olarak uluslararası bilimsel yayınların sayısı da her geçen yll katlanarak artmaktadir. Acil tıp kategorisi dışındaki dergilerin daha çok tercih edilmesi, acil tıp konulu yayınların çokluğu, üniversite hastanelerinin katkisı dikkat çekicidir. Çok merkezli ve etki faktörü yüksek dergilerde yayınlanan çalışmaların azlığ yayın sayısı kadar yayın kalitesi konusuna da önem verilmesi gerektiğini düşündürmektedir.
\end{abstract}

Key Words:

Emergency Medicine,

Article,

Publication,

Turkey.

Anahtar Kelimeler:

Acil Tip,

Makale,

Yayın,

Türkiye.

\section{INTRODUCTION}

Emergency Medicine (EM) is a branch of medicine in which life-threatening situations must be quickly recognized and rapid clinical interventions made. Emergency medicine is focused especially on the solution of urgent health problems due to pre- hospital and hospital emergency services to improve the quality of services offered and prevent death and disability. Emergency Medicine, as a medical specialty, was born as the needs of society. Emergency medical services, as we know, today started in 1960. First, in the United States, it has 
emerged as a separate field of expertise. In 1970, the first time the department of emergency medicine at the University of Cincinnati has been established (1). Emergency Medicine, in Turkey, despite having a history of 20 years, showed a very rapid development. In 1993 The Emergency Medicine was recognized as a separate field in Turkey. In 2015, 42 university hospitals, 27 training and research hospitals, eight affiliated training and university hospitals, 7 affiliated private and university hospitals, and 2 affiliated training and foundation university hospitals; in total, 86 emergency clinics and departments have training programs of residency for emergency medicine (1). In the current distribution, over 1000 professionals have been trained (1). More than 1000 Emergency medicine experts are working in 81 provinces (1). The number of emergency medicine professors is more than 50, and associate professors are more than 100 in Turkey (1). The scientific research in Turkey, despite the known increase in the number and nature of the data, are limited. This study aimed to present characteristics of internationally published articles about emergency medicine originating from Turkey.

\section{MATERIAL AND METHOD}

Our study was designed as a retrospective observational study that did not involve human subjects and was considered exempt from informed consent. Publications about emergency medicine originated from Turkey between 1st January 200230th December 2012 were searched in the International Scientific Indexing (ISI) Web of Knowledge database, Science Citation Index (SCI), and Science Citation Index-Expanded (SCIExpanded). The publications were included in the analysis only if they contained the word "emergency" in the primary author affiliation field. Two thousand articles were found, a total of 1812 articles were included, 188 articles associated with engineering were excluded.

Selected articles were classified as Training and Research Hospitals Emergency Departments, State Hospitals Emergency Medicine Clinics, University Hospitals Emergency Medicine Departments, Military Hospitals, Foundation Universities, private hospitals, and other clinics. Published articles were examined according to years; the annual growth rates were calculated. The subjects of the articles were classified under the main headings of emergency medicine toxicology, trauma, emergency medicine and management, general surgery, neurology, pulmonology, cardiology, internal medicine, obstetrics and gynecology, radiology. Number of centers participating in the study, the specialties of authors in primary and secondary author affiliation field, Turkish \& foreign collaborators articles were classified in terms of clinical branches. Journals were classified as Emergency Medicine (EM) or non-Emergency
Medicine (non-EM) according to a standardized list published by Thompson Scientific Journal Citation Reports (2). According to Thompson Scientific, EM journals are considered as ones that concentrate on the science, education and clinical practice of emergency medicine' and cover the 'breadth of the specialty on trauma, pediatrics, toxicology, injury prevention and control, resuscitation and emergency medical services.' Emergency medical journals that articles were frequently published and non-emergency medicine journals, the impact factors of the journals in 2013, and the total number of publications have been identified (3). For statistical analysis of data, the Number Cruncher Statistical System (NCSS) 2007 \& Power Analysis and Sample Size (PASS) 2008 Statistical Software (Utah, USA) was used. For evaluation of the data, descriptive statistical methods (mean, standard deviation, frequency, rate, minimum, maximum) were used.

\section{RESULTS}

In our study 1812 articles were included. The articles were analyzed according to branches, $95,9 \%(n=1737)$ were from medical faculty, 2,9\% $(n=53)$ were from school of nursing, 0,9\% $(n=16)$ from dentistry and $0,3 \%(n=6)$ from veterinary medicine. When the articles were annalyzed acording to subjects, $14,7 \%(n=266)$ were about trauma, $14,0 \%(n=253)$ about emergency medicine and management, $12,5 \%(n=226)$ about cardiology and cardiovascular surgery, $11,5 \%(n=209)$ about general surgery, 8,8\% $(\mathrm{n}=159)$ about toxicology (Graphic 1).

The distribution of published articles per year has been increasing steadily (Graphic 2). Emergency medicine publications in the last five years increased at a rate of $4,6 \%$. The number of publications is 1165 (64,3\%).

Considering the number of centers of publications 1366 publications were single centered, 446 publications were found to be multicentered. The number of authors in the publications varies between one to twenty, was found to be an average of five authors. One thousand two hundred of the authors in the first author affiliation field were from university hospitals, 101 from foundation university, 336 from research and training hospitals, 50 from state hospitals, 71 from military hospitals.

When we look at the first and second author's affiliation fields, emergency medicine ranks first with 459/364. The next closest is general surgery 210/177, then cardiology 205/189, and pediatrics $119 / 113$ follows it, respectively.

When we look at the disciplines in the first and second author's affiliation fields, emergency medicine exceeds the other disciplines with 520 publications. Emergency medicine physicians work most frequently on emergency medicine and management, toxicology, and trauma. 


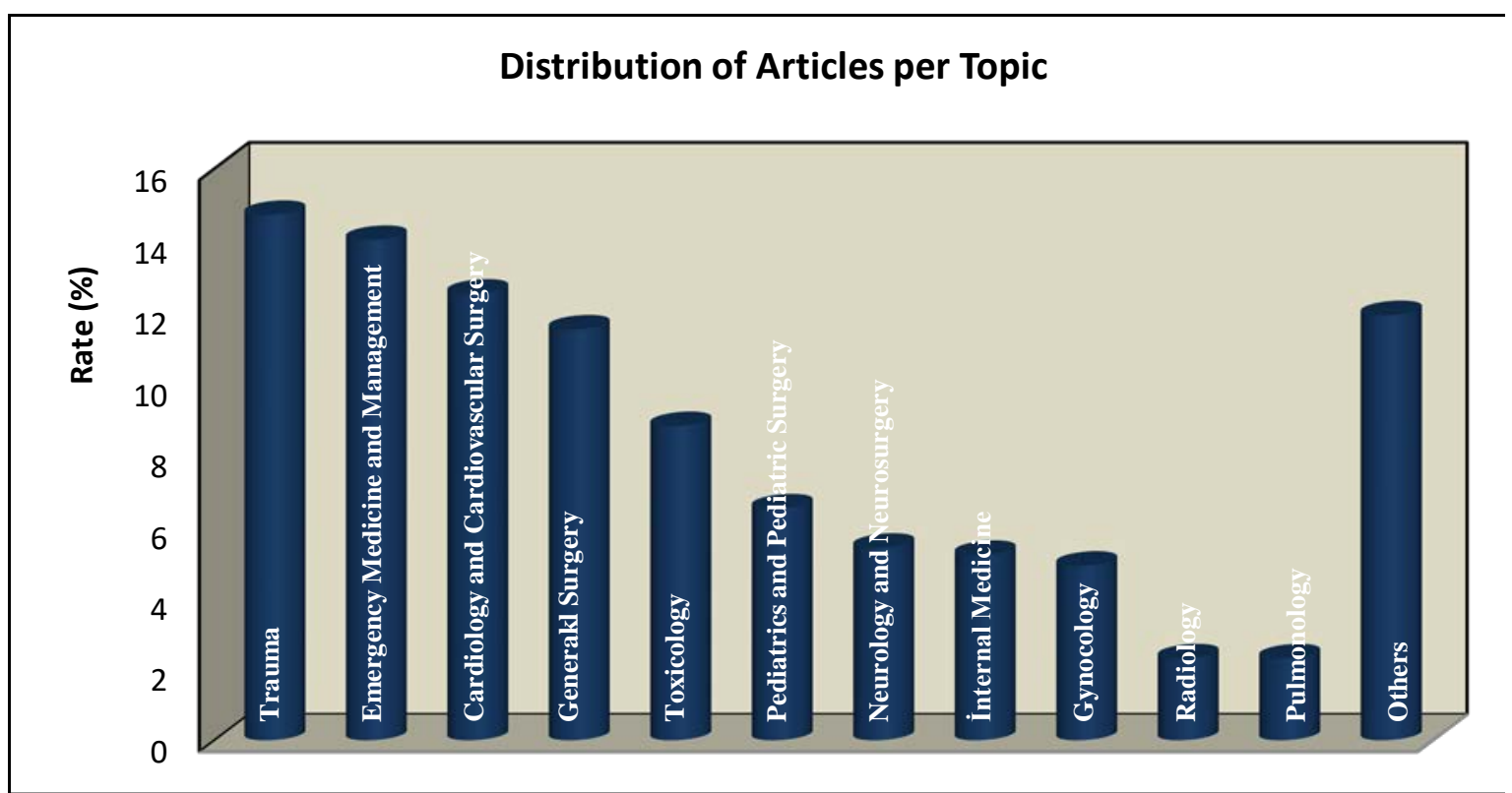

Graphic 1: Distribution of articles per topic

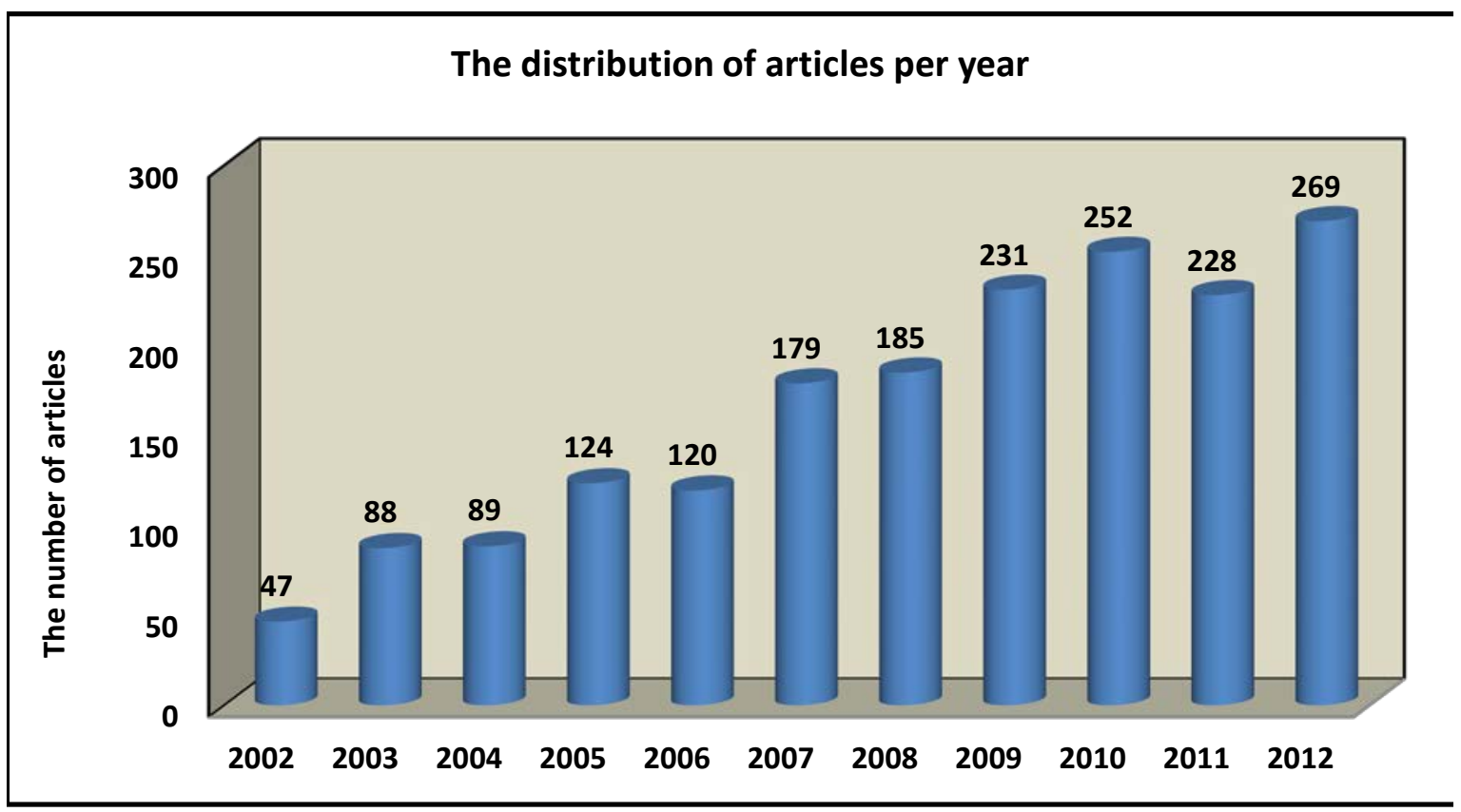

Graphic 2: The distribution of articles per year

The distribution of publications first and second authors consisting of emergency medicine physicians per year and hospitals is below (Table 1).

Articles published in non-EM journals were 1416 (78,1\%), and in EM journals were 396 (21,9\%). In the EM category, the "Turkish Journal of Trauma and Emergency Surgery" ranks first with 134 articles. The rank was followed by "Emergency Medicine Journal" with 43 articles, "American Journal of Emergency Medicine” with 41 articles, "Hong Kong Journal of Emergency Medicine" with 39 articles, and "European Journal of Emergency Medicine” with 33 articles, respectively (Table 2).
In the non-EM journal category, "Turkish Clinics" journal ranks first with 46 articles, followed by "Advances in Therapy" with 32 articles, "Turkish Journal of Thorax and Cardiovascular Surgery" with 31 articles, "Human and Experimental Toxicology” with 27 articles (Table 3).

When we look at the Turkish-Foreign departments worked together, emergency medicine made publications most, followed by psychiatry and cardiology. When we look at the hospitals, the training and research hospitals, and state hospital researches progressively increased in the past five years, despite university and foundation university publications stayed stable. 
Table 1: The distribution of publications first and second authors consisting of emergency medicine physicians per years and hospitals

\begin{tabular}{ccccccccc}
\hline $\begin{array}{c}\text { Publications } \\
\text { written by } \\
\text { emergency } \\
\text { physicians }\end{array}$ & $\begin{array}{c}\text { University } \\
\text { Hospitals }\end{array}$ & $\begin{array}{c}\text { Foundation } \\
\text { Universities }\end{array}$ & $\begin{array}{c}\text { Training } \\
\text { and } \\
\text { Research } \\
\text { Hospitals }\end{array}$ & $\begin{array}{c}\text { State } \\
\text { Hospitals }\end{array}$ & $\begin{array}{c}\text { Private } \\
\text { Hospitals }\end{array}$ & $\begin{array}{c}\text { Foreign } \\
\text { Hospitals }\end{array}$ & $\begin{array}{c}\text { Military } \\
\text { Hospitals }\end{array}$ & Total \\
\hline 2002 & 7 & 0 & 0 & 0 & 0 & 0 & 1 & $\mathbf{8}$ \\
2003 & 9 & 1 & 0 & 0 & 0 & 0 & 1 & $\mathbf{1 1}$ \\
2004 & 21 & 0 & 1 & 0 & 0 & 0 & 1 & $\mathbf{2 3}$ \\
2005 & 35 & 0 & 2 & 0 & 0 & 0 & 2 & $\mathbf{3 9}$ \\
2006 & 31 & 0 & 0 & 0 & 4 & 0 & 1 & $\mathbf{3 6}$ \\
2007 & 42 & 0 & 0 & 1 & 0 & 0 & 3 & $\mathbf{4 6}$ \\
2008 & 40 & 2 & 2 & 1 & 2 & 0 & 0 & $\mathbf{4 7}$ \\
2009 & 55 & 1 & 6 & 1 & 1 & 0 & 1 & $\mathbf{6 5}$ \\
2010 & 63 & 5 & 9 & 4 & 3 & 2 & 1 & $\mathbf{8 7}$ \\
2011 & 48 & 3 & 8 & 3 & 0 & 1 & 3 & $\mathbf{6 6}$ \\
2012 & 59 & 2 & 16 & 7 & 0 & 1 & 7 & $\mathbf{9 2}$ \\
Total & $\mathbf{4 1 0}$ & $\mathbf{1 4}$ & $\mathbf{4 4}$ & $\mathbf{1 7}$ & $\mathbf{1 0}$ & $\mathbf{4}$ & $\mathbf{2 1}$ & $\mathbf{5 2 0}$ \\
\hline
\end{tabular}

Table 2: Distribution of Articles per Journals Classified As Emergency Medicine Journals (Thompson Scientific 2013)

\begin{tabular}{|c|c|c|c|}
\hline $\begin{array}{l}\text { Emergency Medicine } \\
\text { Journals }\end{array}$ & $\mathbf{n}$ & $\%$ & $\begin{array}{l}\text { Impact } \\
\text { Factor }\end{array}$ \\
\hline $\begin{array}{l}\text { Turkish J. of Trauma and } \\
\text { Emergency Surgery }\end{array}$ & 134 & 33,8 & 0,342 \\
\hline Emergency Medicine Journal & 43 & 10,9 & 1,645 \\
\hline $\begin{array}{l}\text { American J. of Emergency } \\
\text { Medicine }\end{array}$ & 41 & 10,4 & 1,704 \\
\hline $\begin{array}{l}\text { Hong Kong J. of Emergency } \\
\text { Medicine }\end{array}$ & 39 & 9,8 & 0,132 \\
\hline $\begin{array}{l}\text { European J. of Emergency } \\
\text { Medicine }\end{array}$ & 33 & 8,3 & 1,021 \\
\hline J. of Emergency Medicine & 31 & 7,8 & 1,331 \\
\hline Pediatric Emergency Care & 11 & 2,8 & 0,891 \\
\hline $\begin{array}{l}\text { Annals of Emergency } \\
\text { Medicine }\end{array}$ & 9 & 2,3 & 4,285 \\
\hline $\begin{array}{l}\text { İnjury İnt. J. of The Care And } \\
\text { İnjured }\end{array}$ & 9 & 2,3 & 1,931 \\
\hline $\begin{array}{l}\text { Academic Emergency } \\
\text { Medicine }\end{array}$ & 4 & 1 & 1,757 \\
\hline J. of Emergency Nursing & 4 & 1 & 0,802 \\
\hline $\begin{array}{l}\text { Scandinavian J. of Trauma } \\
\text { Resuscitation } \\
\text { And Emergency Medicine }\end{array}$ & 3 & 0,8 & 1,68 \\
\hline Resuscitation SCI & 2 & 0,5 & 4,104 \\
\hline $\begin{array}{l}\text { Emergency Medicine } \\
\text { Australasia }\end{array}$ & 2 & 0,5 & 0,993 \\
\hline Unfall Chirurgic & 1 & 0,3 & 0,64 \\
\hline Others & 30 & 7,6 & \\
\hline Total & 396 & 100,0 & \\
\hline
\end{tabular}

Table 3: Distribution of Articles per Journals Classified as Non-Emergency Medicine Journals (Thompson Scientific 2013)

\begin{tabular}{lccc}
\hline $\begin{array}{l}\text { Non-Emergency Medicine } \\
\text { Journals }\end{array}$ & n & \% & $\begin{array}{c}\text { Impact } \\
\text { Factor }\end{array}$ \\
\hline Turkish Clinics & 46 & 3,2 & -- \\
Advances in Therapy & 32 & 2,3 & 2,125 \\
Turkish Journal of Thorax and & 31 & 2,2 & 0,126 \\
Cardiovascular Surgery & 27 & 1,9 & 1,453 \\
Human And Experimental Toxicology & 22 & 1,6 & 0,359 \\
Acta Chirurgica Belgica & 22 & 1,6 & 1,546 \\
Acta Neurochirurgica & 20 & 1,4 & 0,558 \\
Turkish Journal of Pediatrics & 18 & 1,3 & 0,472 \\
Bratislavske Lekarske Listy & 18 & 1,3 & 0,611 \\
Bulletin of Microbiology & 17 & 1,2 & 0,963 \\
Surgery Today & 16 & 1,1 & 0,458 \\
Heart Surgery Forum & 15 & 1,1 & 0,113 \\
Medical Journal of Trakya University & 1132 & 72,6 & \\
Others & 1416 & 100,0 & \\
\hline Total & & & \\
\hline
\end{tabular}

\section{DISCUSSION}

Since 1998, the date of the first emergency medicine specialist graduated the number of publications in international indexes increased steadily. Yanturali et al. evaluated the internationally published articles between 19942004 in Turkey, and they found 84 articles (4). Ersel et al. found 422 internationally published 
articles between 1994-2009, 358 of them were published in SCI-Expanded (5). Dogan evaluated 179 publications of emergency medicine professors and assistant professor about trauma between 19942012 and reported that the number of publications and citations about trauma had been increasing within recent years (6). Kucuk, in his study, including 528 articles published in emergency medicine between 2009-2014, reported that in the last five years, the number of articles published was higher (7). In our study, between the years 20022012, the number of publications in SCI-Expanded in which the first and second names of the author's specialties are emergency medicine is 520 .

Especially, all publications 64.3\% $(\mathrm{n}=1165)$ have been made in the last 5 -year period, the development of emergency medicine started maturation. Yanturali et al. showed an increase in publications in recent years and predicted that there would be a significant increase (4). Our study confirms these predictions come true. Besides, it shows that the same acceleration growth will continue. Ersel et al. also take attention on the increase after 2004 (5). This increase in the number of publications can be associated with the maturation of the departments of emergency medicine clinics and with many specialty thesis added. Besides, the increase of academic emergency medicine specialists with the objectives and priorities for emergency medicine research explains the development. The development of archiving and electronic records systems, the diagnosis be made mandatory, created a more robust database.

The effects of this success of emergency medicine publications from Turkey is mentioned in the international arena. Wilson and his colleagues investigated the characteristics of published emergency medicine articles around the world between the years 1996-2005, the number of publications from Turkey ranks 9, the annual increase of publications ratio is 7,2 and ranks 5 (8). In our study, publications in the last five years were detected to increase at a rate of $4,6 \%$ per year. The serious increase in the number of publications from Turkey shows the concrete evolution of emergency medicine in Turkey.

Analyzing the first author of the publications that work at university hospitals is $66 \%$. Kucuk reported that publications were mostly from universities (7). The universities' leadership can be explained by more research opportunities at universities and additional effort by the academic staff of emergency medicine specialists. Especially the minimum publication requirement for associate professors, affecting the number of publications is an important motivation.

Considering publications of single or multicentered, $75.4 \%$ of publications were singlecentered, 24,6\% were multi-centered in our study. Cinar and his colleagues' publication showed that multi-centered studies have a rate of $14 \%$ (9). Thus indicates that significant improvements are needed in the quality in addition to the increase in the number of publications.

Considering all publications by subjects, trauma (14.7\%), emergency medicine and management (14\%), and cardiology (12.5\%) rank the first three places. Trauma is the most common subject, its easily identifiable nature can explain this, and the first reference location being emergency service. Considering the first and second authors of the articles consisting of emergency medicine physicians, emergency medicine, and management $(37,5 \%)$ ranks the first, followed by toxicology $(19,2 \%)$ and trauma (16,7\%). In Yanturali et al. 's publication, trauma is in the first place, followed by toxicology and cardiology (4). Kucuk reported that toxicology and environmental emergencies $(20,45 \%)$ were the most often related issues followed by trauma and orthopedic (19.31\%), general surgery (6.81\%), and cardiology (6,43\%), respectively (7). Ersel et al. reports that, $1 / 3$ of the subjects is toxicology and environmental emergencies, followed by trauma-orthopedics and pharmacology-biologic markers (5). Also, in Cinar et al.'s publication, toxicology ranks the first (9). The difference in our study may have arisen from the increase of the academic emergency medicine specialists and residents and also of the increase in patients referrals, hence it is on the need for further studies in emergency medicine and management. It is interesting to note that in our country, every five scientific publication of emergency physicians is about toxicology.

An important factor for this is common in our country, the first reference place is emergency services, besides some emergency medicine physicians with a particular interest in this topic affects the frequency of publications on this subject. Based on these results, in the next years, emergency medicine specialists' aim should be to make publications in a wider range.

In our study, non-EM journals are preferred more with a rate of $78,1 \%(n=1416)$. In Cinar and his colleagues' study, the ratio is $58,7 \%$ (9). In the world, non-EM journals are preferred to 58,2\% (8). The difference in our study should not be put forth with the available data, but the journals included can cover their branches' emergencies that are not interested in emergency medicine. In this case, in the Non-EM journal category, the number of articles may have been relatively more.

Overall the reason for preferring Non-EM journals could be of its multidisciplinary nature, the subjects which are of interest in another discipline are also interested in the field. Hence the emergency medicine physicians have more choices in the selection of journals.

In Kucuk's study, the publications were mostly in the "American Journal of Emergency Medicine," 
followed by the "Turkish Journal of Trauma and Emergency Surgery" (7). Cinar et al. mentioned that in the emergency medicine group, the publications are collected in five journals (9). "Turkish Journal of Trauma and Emergency Surgery" in this group (9.5\%) takes the first place as its a national journal, to be broadcast in Turkish, within SCI-E (9). Also, in Ersel and his colleagues' study, the "Turkish Journal of Trauma and Emergency Surgery” ranks first (n=46, 10,9\%) (5). In our study, also "Turkish Journal of Trauma and Emergency Surgery” ranks first $(n=134,7,3 \%)$. It is pleasant to have a journal from our country in the emergency medicine category indexed in the PubMed database in SCI-E. Considering the development of emergency medicine and the serious stance of emergency medicine journals, soon more journals from our country will anticipate in this category (9).

On the other hand, the low number of publications in important and high impact factor emergency journals like Annals of Emergency Medicine, Academic Emergency Medicine, Resuscitation, and Injury is engrossing. One reason for this is difficulty publishing articles in these journals, although a minority of well-designed high-quality scientific researches. Although the impact factor is causing controversy, the strongest correlation is found between published articles' methodological strength and citation of articles (9-15). Therefore, it was appropriate that there is a relationship between high impact factor journals and the quality of the broadcast.

In 2009 TÜBİTAK-ULAKBİM published "Scientific Publications Index 1981-2007 in Turkey", Turkey has taken 26th place in 45 countries (13). However, when the number of citations per publication (impact factor) is examined for these 27 years, Turkey, with an impact factor of 4.55 , is 42 nd of 45 countries (13). In the same report in the emergency medicine field, 193 publications were made, 329 citations are referred to them, and the impact factor is calculated as 1,70 (9-16). Although some authors say that there is a lack of evaluation power of the impact factor, it is still the most widely used evaluation criterion in measuring publication quality $(16,17)$. As outlined in this report, the broadcast-quality problem is not only related to emergency medicine in Turkey, which is a common problem for all disciplines. It is a multidimensional problem, including many factors as the shortage of resources allocated to scientific research.
In 2015 according to TUBITAK data, Turkey came 18th in the world according to the number of scholarly publications (17). Yet, the scientific impact of these publications according to their citations is well below the average of the world, the European Union (EU) and the Organisation for Economic Co-operation and Development (OECD) countries (17). Only $20 \%$ of papers' citation impact is above the world's average (17).

There is another important issue in our country that publications usually are made for academic career. But in general, after reaching the "assistant professor” level, the publication rate goes down. Calıskan et al. reported that after getting an assistant professor degree, the rate of publications in international journals of emergency specialists in Turkey decreased (18).

\section{CONCLUSION}

Emergency medicine research output is increasing worldwide. Publications are increasing steadily, also should aim at the high impact factor journals. Most of the articles originating from emergency medicine departments worldwide were published in Non-EM journals.

In conclusion, in a short time, Turkish Emergency Medicine has grown up and reached its goals according to the number of broadcast, but the quality remind controversial. So from now on, this rate of publication should continue, and highquality publications must be the primary goal in the Turkish Emergency Medicine branch.

\section{LIMITATIONS}

The most important limitation of our study is that only published journals in the ISI Web of Knowledge database are included. Although it is a large database, some articles in international journals have remained outside the scope of the study. Still, many journals in the field of emergency medicine published in national journals remain outside the scope of this study. This study presented characteristics of internationally published articles about emergency medicine originating from Turkey, the results obtained from the database include significant portion if not the entire universe, therefore does not constitute an obstacle to get an idea of the entire universe.

\section{Conflicts of Interest}

All other co-authors have no conflicts of interest.

\section{REFERENCES}

1. Acil Tip Nedir? Downloaded from www.acilci.net/acil-tip-nedir/ at 15.10.2019. 
2. Thompson Scientific Journal Citation Reports Downloaded from http://scientific.thomson.com/products/jcr/ at 20.09.2013.

3. Journal Impact Factors List 2013. JCR-Impact-Factors-List-2013 - DTFL Downloaded from dtfl.snu.ac.kr/cgibin/spboard/board.cgi?id=news2\&action at 30.09.2013.

4. Yanturali S, Aksay E, Cevik AA. International Publications from Turkish Emergency Medicine Departments: analysis of first ten years. Turkish J Emerg Med 2004; 4: 170-3.

5. Ersel M. et al. International publications of Academic Emergency Medicine Departments in Turkey: 15th year analysis. Turkish J Emerg Medicine 2010; 10: 55-60.

6. Dogan NO. Evaluation of International Scientific Publications and Citations on Trauma Authored by Professors and Associate Professors of Emergency Medicine in Turkey. Tr J Emerg Med 2013;13(2):64-68.

7. Kucuk E. Contribution of Emergency Medicine Clinics to International Literature in Turkey: Evaluation of Last 5 Years. Sakarya Med J 2015;5(3):119-124.

8. Wilson MP, Itagaki MW. Characteristics and trends of published emergency medicine research. Acad Emerg Med 2007; 14: 63540 .

9. Çınar O. et al. Contribution of Turkish Emergency Medicine to the international literature: evaluation of 15 years. Ulus Travma Acil Cerrahi Derg 2011; 17. 3: 248-252.

10. Aksay E, Sahin H, Kiyan S et al. Current status of emergency residency training programs in Turkey: after 14 years of experience. Eur J Emerg Med 2009; 16: 4-10.

11. Callaham M, Wears RL, Weber E. Journal prestige, publication bias, and other characteristics associated with citation of published studies in peer-reviewed journals. JAMA 2002; 287: 2847-50.

12. Patsopoulos NA, Analatos AA, Ioannidis JP. Relative citation impact of various study designs in the health sciences. JAMA 2005; 293: 2362-6.

13. Tubitak-Ulakbim Downloaded from http://www.ulakbim.gov.tr/cabim/yayin/tbyg_1981_2007/ektablo2. pdf. at 18.08.2010.

14. National Library of Medicine. Downloaded from http://www.nlmw.nih.gov/pubs/factsheets/ factsubj.html. at 12.09.2013.

15. Usubutun A, Balcı S, Al P. Evaluation of Articles from Turkey Published in Pathology Journals indexed in international indexes. Turkish Journal of Pathology. 2010; 26:2:10 7-113.

16. Al U, Soydal I. An Evaluation on Turkey Addressed Journals in Citation Indexes. Information World, 2011,12 (1) 13-29

17. Tonta Y. TUBITAK Türkiye Adresli Uluslararası Bilimsel Yayınları Teşvik (UBYT) Programının Değerlendirilmesi. TUBITAK ULAKBIM, Ankara.

18. Tur FC, Aksay E. Publishing by Emergency Medicine Physicians: Only for Academic Advancement? Tr J Emerg Med 2012;12(2):77-81. 